\title{
CHANGES OF HAEMATOLOGICAL INDICES OF JUVENILE CARP (Cyprinus carpio L.) UNDER THE INFLUENCE OF NATURAL POPULATIONS OF CYANOBACTERIAL WATER BLOOMS
}

\author{
R. KOPP, J. HETEŠA \\ Fishery and Hydrobiology Departament, \\ Mendel University of Agriculture and Forestry, Brno, Czech Republic \\ Received May 10, 1999 \\ Accepted May 31, 2000
}

Abstract

Kopp R., J. Heteša: Changes of haematological indices of juvenile carp (Cyprinus carpio L.) under the influence of natural populations of cyanobacterial water blooms. Acta Vet. Brno 2000, 69: 131-137.

The aim of the presented paper was to evaluate the effect of cyanobacterial water blooms common in eutrophic reservoirs on blood indices of carp. A total of 180 individuals of juvenile carp (Cyprinus carpio L.) of the average body mass $36.9 \mathrm{~g}$ (1996) and $26.3 \mathrm{~g} \mathrm{(1997)} \mathrm{were} \mathrm{used} \mathrm{in} \mathrm{the}$ experiments. The experimental fish were exposed to 4 different natural populations of cyanobacterial water blooms.

In 1996, the populations of filamentous cyanobacteria (WB I) formed by Anabaena flos-aquae $(90 \%)$ and Aphanizomenon flos-aquae $(10 \%)$ at a concentration of $5.6 \times 10^{4}-3.2 \times 10^{5}$ cells.ml ${ }^{-1}$ without the presence of microcystins and colonial cyanobacteria Microcystis ichthyoblabe $(80 \%)$ with subdominant Microcystis aeruginosa (20\%) (WB II) at a concentration of $2.6 \times 10^{5}$ $3.6 \times 10^{6}$ cells $\cdot \mathrm{ml}^{-1}$ with detected Microcystin LR $\left(17.2 \mu \mathrm{g} \cdot \mathrm{g}^{-1}\right.$ of dry mass) were used. Exposure time was $168 \mathrm{~h}$ for filamentous species and $96 \mathrm{~h}$ for colonial species. In 1997 the monospecies population of filamentous cyanobacteria Anabaena flos-aquae (WB III) at a concentration of $5.3 \times 10^{4}-7.9 \times 10^{4}$ cells $\cdot \mathrm{ml}^{-1}$ containing two different microcystins (total concentration $56.06 \mu \mathrm{g} \cdot \mathrm{g}^{-1}$ of dry mass) and water bloom (WB IV) formed by colonial species Microcystis ichthyoblabe $(40 \%)$ and Microcystis aeruginosa $(30 \%)$ with filamentous Anabaena flos-aquae $(30 \%)$ at a concentration of $1.8 \times 10^{6}-1.4 \times 10^{7} \mathrm{cells} \cdot \mathrm{ml}^{-1}$ which contained three microcystins (total concentration $289.3 \mu \mathrm{g} \cdot \mathrm{g}^{-1}$ of dry mass) were used. Both populations were exposed for $48 \mathrm{~h}$. Control fish in both tests were kept in treated drinking water infused $24 \mathrm{~h}$ before the start of the experiment.

Haematological examination showed significant changes $(p<0.05)$ in leukocrit $(\mathrm{BC})$ of fish exposed to the cyanobacterial population WB I, and in haematocrit (PCV) values, total protein concentration (TP), ALT and AST activities in fish exposed to the population WB II as compared to control fish. LDH activity in blood plasma of carp exposed to cyanobacterial population WB II was increased $(p<0.01)$ as compared to control fish. TP values from cyanobacterial populations WB III a WB IV were significantly reduced $(p<0.05)$ and values of ALT activities increased $(p<0.01)$. Moreover, significant increase $(p<0.05)$ of AST activity was recorded for fish exposed to cyanobacterial water bloom WB III.

The observations confirmed adverse effects of cyanobacterial biomass on juvenile carp. The effect of toxic water bloom populations was manifested by changes of blood plasma indices. Toxins supply here water the role of catalyzers enhancing the negative influence of toxic high ammonia values.

Carp, cyanotoxins, water blooms, plasma enzymes

Cyanobacteria as photosynthesizing organisms produce biologically active compounds that may affect growth and development of other water organisms and physical and chemical characteristics of water (Maršálek and Turánek 1996). Great attention has recently been paid to the impact of cyanobacterial toxins on fish. Clinical symptoms of poisoning, pathological changes and influence on blood indices have been investigated as well.

Address for correspondence:

Ing. Radovan Kopp,

Dep. Fishery and of Agriculture and Forestry,

Nejdecḱ́ 600,691 4robiology,

Phone: +420627340125

http://www.vfu.cz/acta-vet/actavet.htm 
Maximum of toxins is absorbed into the fish organism through the gastrointestinal tract, whereas toxin penetration through the skin or gills is negligible (Tencalla et al. 1994). Toxic influence of Microcystin LR on carp after oral administration was manifested by torpidity and loss of reflexes, skin haemorrhages, eye chamber and in internal organs. Considerable damage were found for fish kidney and liver (Navrátil et al. 1996, 1997).

Intraperitoneal exposure to microcystins causes tissue damage in fish liver as demonstrated by significant increase of alanine aminotransferase (ALT), aspartate aminotransferase (AST) and lactate dehydrogenase (LDH) activities ( Rabergh et al. 1991; Navrátil et al. 1998). Toxic effect on fish exposed to media containing the dispersed microcystin is manifested in delay caused by limited penetration into the healthy fish. Toxic effect after the oral administration is approximately 10 times lower than after the intraperitoneal application (Carbis et al. 1996a).

Long-term impact of the cyanobacteria containing microcystins at lower concentrations is relatively difficult to observe in individual fish; therefore it is more suitable is to check a larger number of fish. The observation of aminotransferase (ALT, AST), bile acids, bilirubin, sodium and chloride from the blood serum is recommended (Carbis at al. 1996b).

\section{Materials and Methods}

Juvenile carps were kept during $48 \mathrm{~h}$ before the start of the experiment in laminated basins $\left(0.5 \mathrm{~m}^{3}\right)$ and subsequently were relocated into the permanently aerated 100 -litre aquaria (10 piece/aquarium).

A total of 100 juvenile carp ( 90 experimental and 10 control fish) of mean weight $36.9 \pm 7.9 \mathrm{~g}$ were used in experiment A (29. 7. - 5. 8. 1996). Fish were fed a diet Alma ( $20 \%$ of N-substances, $13 \%$ of fat) at the dose of 2 $\%$ of the fish-stock weight. During the last $48 \mathrm{~h}$ of the experiment no food was available.

The experimental fish were exposed to two natural cyanobacterial water bloom populations for 168 and $96 \mathrm{~h}$, respectively. No microcystins were detected in cyanobacterial population WB I, Microcystin LR $\left(17.2 \mu \mathrm{g} \cdot \mathrm{g}^{-1}\right.$ of dry mass) was found in population WB II.

During the experiment, water temperature ranged between $22.8-26.8{ }^{\circ} \mathrm{C}$, dissolved oxygen concentration reached $24-98 \%$ and $\mathrm{pH}$ was $7.7-8.4$. The values of ammonia $\mathrm{N}-\mathrm{NH}_{3}{ }^{+}$varied between $0.04-1.08 \mathrm{mg} \cdot \mathrm{l}^{-1}$.

Juvenile carp (70 experimental and 10 control fish) of mean weight $26.3 \pm 7.8$ g were used in experiment B (12. 8. - 14. 8. 1997). The experimental fish were again exposed to two natural cyanobacterial water bloom populations for the duration of $48 \mathrm{~h}$ without feeding. Cyanobacterial population WB II contained 2 microcystins (total toxin concentration $52.0 \mu \mathrm{g} \cdot \mathrm{g}^{-1}$ of dry mass). In population WB IV 3 microcystins were found with total concentration $193.9 \mu \mathrm{g} \cdot \mathrm{g}^{-1}$ of dry mass.

During the experiment, water temperature ranged between $23.7-26.9{ }^{\circ} \mathrm{C}$, dissolved oxygen concentration reached 56-122\% and $\mathrm{pH} 7.7-8.5$. The values of ammonia $\mathrm{N}^{-\mathrm{NH}_{3}}{ }^{+}$varied between $0.02-0.36 \mathrm{mg} \cdot \mathrm{l}^{-1}$.

Differences in values of monitored physical and chemical characteristics among particular aquarium were negligible for both of experiments, occurrence of low values of dissolved oxygen were momentary (see Fig. 1 and 2). Control fish for both of experiments were kept in the treated drinking water.

Cyanobacterial biomass was evaluated by chlorophyll $\boldsymbol{a}$ concentrations (Št ěpánek et al. 1982), and by number of cells counted in Bürker's counting chamber. High-performance liquid chromatography (HPLC) was used for the analyses of microcystins in all chosen cyanobacterial populations. These analyses were performed at the Veterinary Research Institute in Brno.

Blood samples of 52 fish in experiment A and of 40 fish in experiment B were taken from the head into the heparinised tubes after the termination of the exposure time. Additional processing of blood and plasma separation were carried out after S vobod ová et al. (1986). Values of haemoglobin (Hb), haematocrit (PCV), leukocrit (BC) and corpuscular haemoglobin concentration (MCHC) were determined by standard methods ( $\mathrm{S}$ vobodová et al. 1986). Commercial kit (Lachema Diagnostika, Czech Republic) was used for the detection of total protein (TP) concentration in blood plasma. Activities of aminotransferases (ALT, AST) were detected by the commercial kit Humanzym UV test (Human, Germany), activity of lactate dehydrogenase (LDH) was detected by LDH 105 UV kit (Lachema Diagnostika, Czech Republic).

Statistical evaluation of results (Student's $t$-test) was done using the software Microsoft Excel 97.

\section{Results}

Results of haematological examinations are presented in the Tables 1 and 2.

Statistical evaluation of the influence of cyanobacterial population (WB I) on haematological indices of the juvenile carp showed distinct decrease of leukocrit (BC) 
Table 1

Haematological indices of juvenile carp blood (experiment A)

\begin{tabular}{|c|c|c|c|c|}
\hline \multicolumn{2}{|l|}{ Experiment A (1996) } & WB I (168 h) & WB II (96 h) & Control \\
\hline chlorophyll $\boldsymbol{a}\left(\mu \mathrm{g} \cdot 1^{-1}\right)$ & mean & 40.18 & 28.83 & \\
\hline cells $\cdot \mathrm{ml}^{-1}$ & mean & $1.8 \cdot 10^{5}$ & $1.8 \cdot 10^{6}$ & \\
\hline fish & $n$ & 21 & 24 & 7 \\
\hline $\mathrm{N}-\mathrm{NH} 3\left(\mathrm{mg} \cdot \mathrm{l}^{-1}\right)$ & $\min -\max$ & $0.04-1.08$ & $0.06-0.42$ & $0.05-0.59$ \\
\hline $\mathrm{Hb}\left(\mathrm{g} \cdot \mathrm{l}^{-1}\right)$ & $\begin{array}{c}\text { mean } \\
\mathrm{SD}\end{array}$ & $\begin{array}{l}51.32 \\
10.65\end{array}$ & $\begin{array}{r}55.75 \\
7.60\end{array}$ & $\begin{array}{r}55.17 \\
6.26\end{array}$ \\
\hline $\operatorname{BC}\left(1 \cdot 1^{-1}\right)$ & $\begin{array}{c}\text { mean } \\
\text { SD }\end{array}$ & $\begin{array}{r}* 0.0078 \\
0.0020\end{array}$ & $\begin{array}{l}0.0083 \\
0.0012\end{array}$ & $\begin{array}{l}0.0096 \\
0.0015\end{array}$ \\
\hline $\operatorname{PCV}\left(1 \cdot 1^{-1}\right)$ & $\begin{array}{c}\text { mean } \\
\text { SD }\end{array}$ & $\begin{array}{l}0.25 \\
0.07\end{array}$ & $\begin{array}{r}* 0.25 \\
0.04\end{array}$ & $\begin{array}{l}0.29 \\
0.03\end{array}$ \\
\hline $\operatorname{MCHC}\left(1 \cdot 1^{-1}\right)$ & $\begin{array}{c}\text { mean } \\
\text { SD }\end{array}$ & $\begin{array}{l}0.13 \\
0.04\end{array}$ & $\begin{array}{l}0.15 \\
0.02\end{array}$ & $\begin{array}{l}0.12 \\
0.03\end{array}$ \\
\hline $\mathrm{TP}\left(\mathrm{g} \cdot \mathrm{l}^{-1}\right)$ & $\begin{array}{c}\text { mean } \\
\text { SD }\end{array}$ & $\begin{array}{r}27.72 \\
4.25\end{array}$ & $\begin{array}{r}* 23.25 \\
3.66\end{array}$ & $\begin{array}{r}25.76 \\
1.31\end{array}$ \\
\hline $\operatorname{ALT}\left(\mu \mathrm{kat} \cdot 1^{-1}\right)$ & $\begin{array}{c}\text { mean } \\
\mathrm{SD}\end{array}$ & $\begin{array}{l}1.07 \\
0.51\end{array}$ & $\begin{array}{r}* 1.44 \\
0.61\end{array}$ & $\begin{array}{l}1.12 \\
0.12\end{array}$ \\
\hline $\operatorname{AST}\left(\mu \mathrm{kat} \cdot \mathrm{l}^{-1}\right)$ & $\begin{array}{c}\text { mean } \\
\text { SD }\end{array}$ & $\begin{array}{l}5.02 \\
2.21\end{array}$ & $\begin{array}{r}* 6.50 \\
3.25\end{array}$ & $\begin{array}{l}4.36 \\
1.61\end{array}$ \\
\hline LDH $\left(\mu \mathrm{kat} \cdot \mathrm{l}^{-1}\right)$ & $\begin{array}{c}\text { mean } \\
\mathrm{SD}\end{array}$ & $\begin{array}{r}21.30 \\
6.14\end{array}$ & $\begin{array}{r}* * 28.84 \\
14.64\end{array}$ & $\begin{array}{r}17.91 \\
3.64\end{array}$ \\
\hline
\end{tabular}

WB I - Cyanobacterial water bloom (Anabaena flos-aquae $90 \%$ and Aphanizomenon gracile 10\%). Microcystins were not detected.

WB II - Cyanobacterial water bloom (Microcystis ichthyoblabe $80 \%$ a Microcystis aeruginosa 20\%). Microcystin LR was detected $\left(17.2 \mu \mathrm{g} \cdot \mathrm{g}^{-1}\right.$ of dry mass).

SD - standard deviation. One and two asterisks are used for indicating the significance of differences at the level of $p<0.05$ and $p<0.01$, respectively.

Table 2

Haematological indices of juvenile carp blood (experiment B)

\begin{tabular}{|c|c|c|c|c|}
\hline Experiment B (1997) & & WB III (48 h) & WB IV (48 h) & Control \\
\hline chlorophyll $\boldsymbol{a}\left(\mu \mathrm{g} .1^{-1}\right)$ & mean & 62.08 & 86.67 & \\
\hline cells $\cdot \mathrm{ml}^{-1}$ & mean & $6.4 \cdot 10^{4}$ & $7.2 \cdot 10^{6}$ & \\
\hline fish & $\mathrm{n}$ & 17 & 16 & 7 \\
\hline $\mathrm{N}-\mathrm{NH} 3\left(\mathrm{mg} \cdot \mathrm{l}^{-1}\right)$ & min-max & $0.04-0.36$ & $0.02-0.35$ & $0.06-0.25$ \\
\hline $\mathrm{Hb}\left(\mathrm{g} \cdot \mathrm{l}^{-1}\right)$ & $\begin{array}{c}\text { mean } \\
\mathrm{SD}\end{array}$ & $\begin{array}{c}64.18 \pm \\
6.79\end{array}$ & $\begin{array}{r}61.69 \\
6.90\end{array}$ & $\begin{array}{r}57.57 \\
8.57\end{array}$ \\
\hline TP $\left(g \cdot 1^{-1}\right)$ & $\begin{array}{c}\text { mean } \\
\mathrm{SD}\end{array}$ & $\begin{array}{r}* 23.61 \\
2.20\end{array}$ & $\begin{array}{r}* 23.82 \\
2.47\end{array}$ & $\begin{array}{r}25.50 \\
1.20\end{array}$ \\
\hline $\operatorname{ALT}\left(\mu\right.$ kat..$\left.^{-1}\right)$ & $\begin{array}{c}\text { mean } \\
\mathrm{SD}\end{array}$ & $\begin{array}{r}* * 2.52 \\
0.99\end{array}$ & $\begin{array}{r}* * 2.39 \\
0.47\end{array}$ & $\begin{array}{l}1.51 \\
0.55\end{array}$ \\
\hline $\operatorname{AST}\left(\mu\right.$ kat..$\left.^{-1}\right)$ & $\begin{array}{c}\text { mean } \\
\text { SD }\end{array}$ & $\begin{array}{r}* 10.39 \\
5.55\end{array}$ & $\begin{array}{l}7.53 \\
2.69\end{array}$ & $\begin{array}{l}6.65 \\
1.64\end{array}$ \\
\hline LDH $\left(\mu\right.$ kat..$\left.^{-1}\right)$ & $\begin{array}{c}\text { mean } \\
\text { SD }\end{array}$ & $\begin{array}{l}44.73 \\
30.19\end{array}$ & $\begin{array}{l}34.44 \\
11.02\end{array}$ & $\begin{array}{r}28.89 \\
5.13\end{array}$ \\
\hline
\end{tabular}

WB III - Cyanobacterial water bloom (Anabaena flos-aquae 100\%). Two microcystins were detected, Microcystin LR was not found. Mcyst 1 (3.22 $\mu \mathrm{g} \cdot \mathrm{g}^{-1}$ of dry mass), Mcyst 2 (48.80 $\mu \mathrm{g} \cdot \mathrm{g}^{-1}$ of dry mass).

WB IV - Cyanobacterial water bloom (Microcystis ichthyoblabe 40\%, Microcystis aeruginosa $30 \%$ and Anabaena flos-aquae 30\%). Three microcystins were detected Mcyst 1 (34.48 $\mu \mathrm{g} \cdot \mathrm{g}^{-1}$ of dry mass), Mcyst $2\left(82.20 \mu \mathrm{g} \cdot \mathrm{g}^{-1} \mathrm{of}\right.$ dry mass) and Microcystin LR (77.20 $\mu \mathrm{g} \cdot \mathrm{g}^{-1}$ of dry mass).

$\mathrm{SD}$ - standard deviation. One and two asterisks are used for indicating the significance of differences at the level of $p<0.05$ and $p<0.01$, respectively. 
$(\mathrm{p}<0.05)$ compared to controls. Values of $\mathrm{Hb}, \mathrm{PCV}$ and ALT were lower than in controls, MCHC, TP, AST and LDH were slightly and non-significantly elevated. Red blood cell indices and total protein (TP) oscillated around the lower limit of variations usual for carp (Svobodová et al. 1986) or slightly below it. Activities of blood plasma enzymes were higher compared to usual values.

The toxic effects of the cyanobacterial population (WB II) resulted in significant changes of PCV, TP, ALT, AST $(\mathrm{p}<0.05)$ and LDH $(\mathrm{p}<0.01)$ compared to controls. PCV and TP indices were lower and the activities of blood plasma enzymes were increased. Decrease of $\mathrm{BC}$ values and increase of $\mathrm{Hb}$ and $\mathrm{MCHC}$ values was non-significant. Comparison of the obtained haematological indices of the cyanobacterial population (WB II) with the range of the value variation for carp (Svobodová et al. 1986) is the same as for the previous cyanobacterial population (WB I).

Both cyanobacterial populations in experiment B contained toxins that influenced mainly blood plasma indices. Significant differences in control fish were found for $\operatorname{TP}(p<0.05)$ and ALT $(p<0.01)$ values. Moreover, monocultural population of cyanobacteria (WB III) caused significant increase of AST activity $(p<0.05)$. Hb and TP values were lower as compared to values for controls and ranged around the lower limit of the value variation for carp (Svobodová et al. 1986). The AST, ALT and LDH activities in all studied groups of fish were higher and exceeded the threshold of the range of the value variation ( S v ob od ova et al. 1986).

\section{Discussion}

Rabergh et al. (1991) reported that the values of blood plasma enzymes (ALT, AST and $\mathrm{LDH}$ ) raise in two hours after an intraperitoneal injection of toxin as a consequence of the hepatocyte necrosis. Tencalla et al. (1994) observed already after $48 \mathrm{~h}$ a decrease of their activity, and interpreted this fact as a result of damage of the majority of hepatocytes that were not able to release enzymes into circulatory system. Carbis et al. (1996b) noted a delay of toxic manifestation in fish exposed to water with immersed microcystin. Falconer (1998) and Falconer et al. (1994) presented catalyzing effect of hepatotoxins from blue-green algae negatively enhancing effect of physical and chemical indices $\left(\mathrm{NH}_{3}, \mathrm{O}_{2}, \mathrm{pH}\right)$.

The ammonia values exceeded maximal feasible concentration for carp in all experiments, both of experimental and control fish were influenced. The toxic effect of ammonia caused the death of 9 fish during the experiment A. The influence of these high ammonia concentrations on haematological parameters is supposed. Consequences of ammonia activity implicated histopathological changes of liver of carp from the concentration of $0.1-0.33 \mathrm{mg} \cdot \mathrm{l}^{-1} \mathrm{NH}_{3}$ (Svobodová and Groch 1971). Since these concentrations were observed in experiments, we can suppose influence of ammonia on livers enzyme activity increase.

Nevertheless high ammonia values were measured for both experimental and control fish. Statistically significant differences of haematological parameters among experimental and control fish were ascribed to effect of microcystins operating as co-factors of toxic effect of ammonia.

Cyanobacterial toxins are secondary metabolic products. Since they are endotoxins, they cannot be actively secreted into the environment. However, after the breakdown of water bloom and decomposition of cell walls, cyanotoxins can be released into the water (Maršálek and Turánek 1996). Carp ingest cyanobacteria very rarely. The digestive tract of carp has a slightly alkaline $\mathrm{pH}$, and its enzymes are not able to decompose mucilaginous envelopes of cyanobacteria. Low $\mathrm{pH}$ is essential for more effective lysis. Therefore, fish are mostly endangered by cell toxins of older declining cyanobacterial populations having envelopes partially lysed (Carbis et al. 1997).

Higher temperature through the experiments was the reason of faster cyanobacterial biomass decomposition that was followed by faster toxin release into the water. Chorus and 
Bartram 1999, showed that for young populations $100 \%$ of toxins is located in cells whereas for decaying cells toxin concentration raise in water on values of $70-80 \%$.

Distant toxin concentration was found in particular parts of fish body. If the carp ingests toxin with food 55\% of toxins is stored in musculature, $38 \%$ in digestive tract and the rest is excluded with excrements. In case of toxin presence in water $50 \%$ of toxin was found in skin, $30 \%$ in gills, $18 \%$ in intestines and $2 \%$ in musculature (Maršálek 1996). Ingestion of cyanobacteria by carp during the experiments was minimal, the gills and skin were identified as a main penetration system into organism.

The values of haematological indices correspond well with the results of other authors (Raberg et al. 1991; Tencalla et al. 1994; Carbis et al. 1996ab; Navrátil et al. 1996, 1998; Vajcová et al. 1998). Certain differences are caused mainly by different ways of toxin penetration and by different physiological state of cyanobacterial water bloom populations.

Blood plasma indices appeared as better indicators. Liver enzymes (ALT, AST and LDH) are the most frequently tested enzymes in fish. Their values increase markedly as a consequence of necrosis (Raberg et al. 1991; Tencalla et al. 1994; Navrátil et al. 1998). These results correspond with conclusions of our experiments. The influence of microcystins in cyanobacterial populations (WB II, III, IV) was manifested mainly by enzyme activity increase. These results were also confirmed by statistical analysis.

We suppose that significant changes of haematological parameters were caused by toxic effect of cyanobacteria together with toxic effect of ammonia. We found these differences already in microcystin concentrations of $17.2 \mu \mathrm{g} \cdot \mathrm{g}^{-1}$ of dry mass (cyanobacterial population WB II).

The control of physical and chemical parameters, mainly ammonia and dissolved oxygen concentrations are essential for confirmation of presented results and subsequent experiments.

The rapid increase of metabolic ammonia could be eliminated by prolongation of starvation time of fish and by elimination of feeding during the experiments. Aquaria with higher capacity as well as lower number of experimental fish will decrease these values. Application of semisthatic tests with use of several aquaria with the same cyanobacterial concentration and progressive fish transfer to the others after an increase of toxic ammonia concentration will be suitable.

\section{Změny vybraných hematologických ukazatelů krve plůdku kapra (Cyprinus carpio L.) pod vlivem přírodních populací vodních květů sinic}

Cílem práce bylo zjistit vliv přírodních populací vodních květů sinic, běžně se vyskytujících v eutrofních vodách, na krevní ukazatele kapra obecného.

$\mathrm{K}$ experimentům byl použit plůdek kapra o průměrné individuální hmotnosti $36.9 \mathrm{~g}$ a $26.3 \mathrm{~g}$ v celkovém počtu $180 \mathrm{ks}$. Pokusné ryby byly chovány v prostředí 4 různých druhů vodních květů sinic. V roce 1996 byla použita populace vláknitých sinic WB I (Anabaena flos-aquae $90 \%$ a Aphanizomenon gracile $10 \%$ ) v koncentracích $5.6 \times 10^{-4}$ až $3.2 \times 10^{-5}$ buněk $/ \mathrm{ml}^{-1}$ bez zjištěné přítomnosti microcystinů a populace kokálních sinic WB II (Microcystis ichthyoblabe $80 \%$ a Microcystis aeruginosa $20 \%$ ) v koncentracích $2.6 \times 10^{-5}$ až $3.6 \times 10^{-6}$ buněk/ml ${ }^{-1}$, u které byl detekován Microcystin LR $\left(17.2 \mu \mathrm{g} . \mathrm{g}^{-1}\right.$ sušiny). Celková doba sledování činila 168 h (vláknité sinice), resp. 96 h (kokální sinice). $\mathrm{V}$ roce 1997 byla použita přírodní monokulturní populace sinic WB III (Anabaena flosaquae $100 \%$ ) v koncentracích $5.3 \times 10^{4}$ až $7.9 \times 10^{4}$ buněk $/ \mathrm{ml}^{-1}$, u které byly zjištěny dva typy microcystinů (celková koncentrace $56.06 \mu \mathrm{g} \cdot \mathrm{g}^{-1}$ sušiny) a vodní květ sinic VKS IV (Microcystis ichthyoblabe 40\%, Microcystis aeruginosa $30 \%$ a Anabaena flos-aquae $30 \%)$ v koncentracích $1.8 \times 10^{6}$ až $1.4 \times 10^{7}$ buněk/ml $/ \mathrm{ml}^{-1}$, která obsahovala tři typy microcystinů (celková koncentrace $289.3 \mu \mathrm{g} \cdot \mathrm{g}^{-1}$ sušiny). Doba pozorování u obou 
populací činila $48 \mathrm{~h}$. Kontrolní ryby u obou pokusů byly chovány v upravené vodovodní vodě, napuštěné 24 h před začátkem sledování.

Hematologické vyšetření prokázalo statisticky významné změny $(p<0.05)$ u leukokritu BC (WB I) a u hodnot hematokritu (PCV), koncentrace celkových bílkovin (TP), aktivity alanin-aminotransferázy (ALT) a aspartát-aminotransferázy (AST) (WB II) ve srovnání s kontrolní skupinou ryb. Vysoce statisticky významné zvýšení $(p<0.01)$ bylo zaznamenáno v krevní plazmě kaprů u aktivity laktát-dehydrogenázy (LDH) u populace sinic WB II ve srovnání s kontrolními rybami. Hodnoty ukazatelů TP u plůdku kapra Z prostředí populací sinic WB III a WB IV byly významně sníženy a hodnoty aktivity ALT vysoce významně zvýšeny. U ryb chovaných v prostředí sinic WB III bylo navíc prokázáno významné zvýšení aktivity AST.

Zjištěné údaje svědčí o vlivu biomasy sinic na plůdek kapra, projevující se především u toxických populací vodních květů sinic změnami ukazatelů krevní plazmy. Toxiny zde vystupují v roli katalyzátorů umocňující negativní působení vysokých hodnot toxického amoniaku.

ERSON, J. W., nus carpio L., exposed to dministration. J. Fish

, G. F., ANDERSON, J. W., rpio L., exposed to ossible imlications for fish

látky produkované sinicemi B., KERŠNER, V.,

A, F., TICHÝ, F. 1996: Vliv rník referátů z II. české nech, Vodňany, pp. 56-62 , F., ŠTĚRBA, F., působení cyanotoxinů na dňany, pp. 166-171 ne Effect of Pure Microcystin f Carp (Cyprinus carpio L.).

1: Histopathological effect cterium Microcystis

ic toxicology 20: 131-146

Jednotné metody

ve Vodňanech, Vodňany, 36

AVSKÝ, J., MAŠÍNOVÁ, Biologické metody

1994: Toxicity of trout (Oncorhynchus

e Effect of Intraperitoneally emical and Morphological .). Acta vet. Brno 67: 281-

d (experiment A).

\section{Acknowledgements}

I would like to express appreciation to Dr. Ludek Blaha for microcystin analyses.

\section{References}

CARBIS, C. R., MITCHELL, G. F., ANDERSON, J. W., McCAULEY, I. 1996a: The effects of microcystins on the serum biochemistry of carp, Cyprinus carpio L., when the toxins are administered by gavage, immersion and intraperitoneal routes. J.Fish Diseases 19: 151-159

CARBIS, C. R., RAWlin, G. T., MITCHEll, G. F., ANDERSON, J. W., McCAULEY, I. 1996b: The histopatology of carp, Cyprinus carpio L., exposed to microcystins by gavage, immersion and intraperitoneal administration. J. Fish Diseases 19: 199-207

CARBIS, C. R., RAWLIN, G. T., GRANT, P., MITCHELL, G. F., ANDERSON, J. W., McCAULEY, I. 1997: A study of feral carp, Cyprinus carpio L., exposed to Microcystis aeruginosa at Lake Mokoan, Australia, and possible imlications for fish health. J. Fish Diseases 20: 81-91

CHORUS, I., BARTRAM, J. 1999: Toxic Cyanobacteria in Water. London, WHO Monograph

FALCONER, R., I 1998: Algal Toxins and Human Health. The Handbook of Environmental Chemistry 5 Part C, Berlin Heidelberg

FALCONER, R., I., BURCH, D., M., STEFFENSEN, A., D., CHOICE, M., ERDALE, R., O. 1994: Toxicity of the Blue-Green Alga (Cyanobacterium) Microcystis aeruginosa in Drinking Water to Growing Pigs, as an Animal Model for Human Injury and Risk Assessment. An International Journal, 9: 131-139

MARŠÁLEK, B., TURÁNEK, J. 1996: Biologicky aktivní látky produkované sinicemi vodního květu. In.:Vodní květy sinic. Ed.: MARŠÁLEK, B., KERŠNER, V., MARVAN, P. Nadatio flos - aquae, Brno, pp. 86-100

MARŠÁLEK, B.1996: Perzistence a odstranitelnost cyanotoxinů. In.:Vodní květy sinic. Ed.: MARŠÁLEK, B., KERŠNER, V., MARVAN, P. Nadatio flos - aquae, Brno, pp. 101-114

NAVRÁTIL, S., PALÍKOVÁ, M., VAJCOVÁ, V., ŠTĚRBA, F., TICHÝ, F. 1996: Vliv toxinů sinic na kapří násadu po perorální aplikaci. In: Sborník referátů z II. české ichtyologické konference. VÚRH JU se sídlem ve Vodňanech, Vodňany, pp. 56-62

NAVRÁTIL, S., PALÍKOVÁ, M., VAJCOVÁ, V., TICHÝ, F., ŠTĚRBA, F., MARŠÁLEK, B., NEČA, J. 1997 : Současné vědomosti o působení cyanotoxinů na ryby. In: Sborník z konference “Ochrana zdraví ryb”. Vodňany, pp. 166-171

NAVRÁTIL, S., PALÍKOVÁ, M., VAJCOVÁ, V. 1998: The Effect of Pure Microcystin LR and Biomass of Bluegreen Algae on Blood indices of Carp (Cyprinus carpio L.). Acta vet. Brno 67: 273-279

RABERGH, C. M. I., BYLUND, G., ERIKSSON, J. E. 1991: Histopathological effect of Microcystin LR a cyclic polypeptide from the cyanobacterium Microcystis aeruginosa on common carp (Cyprinus carpio L.). Aquatic toxicology 20: 131-146

SVOBODOVÁ, Z., GROCH, L. 1971: Possibilities of the Diagnosis of Ammonia-Intoxication of Fish. Buletin VÚR Vodňany 1: 9-18

SVOBODOVÁ, Z., PRAVDA, D., PALAČKOVÁ, J. 1986: Jednotné metody hematologického vyšetřování ryb. Edice metodik VÚRH ve Vodňanech, Vodňany, 36 p.

ŠTĚPÁNEK, M. BERNÁTOVÁ, V., KOPŘIVÍK, B., LUKAVSKÝ, J., MAŠÍNOVÁ, L., POKORNÝ, J., SLÁDEČKOVÁ, A., ŠVEC, J. 1982: Biologické metody vyšetřování vod ve zdravotnictví. Avicenum, Praha, 408 p.

TENCALLA, G. F., DIETRICH, R. D., SCHLATTER, CH. 1994: Toxicity of Microcystis aeruginosa peptide toxin to yearling rainbow trout (Oncorhynchus mykiss). Aquatic Toxicology 30: 215-224 
VAJCOVÁ, V., NAVRÁTIL, S., PALÍKOVÁ, M. 1998: The Effect of Intraperitoneally Applied Pure Microcystin LR on Haematological, Biochemical and Morphological Indices of Silver Carp (Hypophthalmichthys molitrix Val.). Acta Vet. Brno 67: 281-287 